TITLE:

\title{
Nipa (Nypa fruticans) sap as a potential feedstock for ethanol production
}

\section{$\operatorname{AUTHOR(S):~}$}

Tamunaidu, Pramila; Matsui, Naohiro; Okimori, Yasuyuki; Saka, Shiro

\section{CITATION:}

Tamunaidu, Pramila ...[et al]. Nipa (Nypa fruticans) sap as a potential feedstock for ethanol production. Biomass and Bioenergy 2013, 52: 96 102

\section{ISSUE DATE:}

2013-05

URL:

http://hdl.handle.net/2433/174338

\section{RIGHT:}

(C) 2013 Elsevier Ltd.; This is not the published version. Please cite only the published version.; この論文は出版社版でありません。引用の際に は出版社版をご確認ご利用ください。 
Nipa (Nypa fruticans) sap as a potential feedstock for ethanol production

Pramila Tamunaidu ${ }^{1}$, Naohiro Matsui ${ }^{2}$, Yasuyuki Okimori ${ }^{2}$ and Shiro Saka ${ }^{1 *}$

${ }^{*}$ Corresponding author:

Shiro Saka

${ }^{1}$ Department of Socio-Environmental Energy Science,

Graduate School of Energy Science, Kyoto University,

Yoshida-honmachi, Sakyo-ku, Kyoto 606-8501, Japan

Tel/Fax: $+81(0) 757534738$

Email address: saka@energy.kyoto-u.ac.jp

${ }^{2}$ The General Environmental Technos Co., Ltd.,

1-3-5 Azuchimachi, Chuo-ku, Osaka 541-0052, Japan 


\section{Abstract}

The current study was initiated to evaluate the potential of sugar saps from nipa (Nypa fruticans) palm as sustainable feedstock for ethanol production. Nipa palms managed as plantations on four sites was chosen for this study with palms within 8 to 100 years of age. All palms studied were found to have the potential to produce sugar saps from 0.4 to $1.2 \mathrm{~L} \mathrm{~d}^{-}$ ${ }^{1}$ per palm. Further chemical characterization of its saps gave a total composition of 159 to $214 \mathrm{~g} \mathrm{~kg}^{-1}$ mainly composed of sucrose, glucose and fructose. In addition, the elemental analysis gave $5 \mathrm{~g} \mathrm{~kg}^{-1}$ of inorganics with $\mathrm{Na}, \mathrm{K}$ and $\mathrm{Cl}$ being its main inorganic elements. Preliminary batch fermentative assays using Saccharomyces cerevisiae showed that nipa saps can be converted to ethanol within 30 to $48 \mathrm{~h}$ in conditions with and without nutrient supplementation. Furthermore, the fermentation trends were similar to sugarcane sap with high ethanol conversions up to $96.9 \%$ and $95.5 \%$ achieved for both nutrient conditions. Further analysis on inorganic elements before and after fermentation showed that specific elements of $\mathrm{Mg}, \mathrm{Ca}, \mathrm{P}$ and $\mathrm{S}$ were significantly reduced and could have assisted the fermentation. Based on the results obtained from sap collection, chemical characterization and fermentation, the ethanol potential from nipa planted at a density of $1000 \mathrm{ha}^{-1}$ would range from $4550-9100 \mathrm{~L} \mathrm{ha}^{-1} \mathrm{y}^{-1}$. Conclusively, nipa sap showed some interesting characteristics which makes it a potential feedstock for ethanol production.

Keywords: Nipa sap; Chemical composition; Fermentation; Saccharomyces cerevisiae; Ethanol 


\section{Introduction}

Currently the global ethanol supply is produced mainly from sugar and starch feedstocks. Sugar crops accounts for $61 \%$ of the total ethanol production while $39 \%$ is from starch feedstocks [1]. The main feedstocks for ethanol at present are sugarcane juice in Brazil, and corn starch in the US. However, growing these feedstocks rely heavily on non-renewable fossil fuels and exploitation of forest lands which has negative social and environmental impacts. Furthermore, the collection for sugar source is usually practiced after cutting down the plant as in sugarcane which consequently produces large biomass waste such as straw, leafs and tops as well as bagasse as residue after juice extraction.

Palms, too, have been a sugar prospective from the ancient times. Two important products of palms are sap and starch. The former is often consumed as fresh beverage, fermented to alcohol or vinegar and even consumed as sugar, whereas the latter is used as staple food. Main sugar-yielding palms like coconut palm (Cocos nucifera), palmyra palm (Borassus flabellifer), sugar palm (Arenga pinnata) and nipa palm (Nypa fructicans), are believed to produce more nutritious sugars than sugarcane [2]. In palms, however, only the infructescence is cut off and the stalk tapped daily to obtain its sugar saps until the stalk shortens or no more sap is produced from the stalk.

However, tapping of palm stalks could be a challenge, e.g., in coconut palm, the stalks could be over $10 \mathrm{~m}$ in height and a tapper has to climb to such extent to obtain the saps. Conversely, in the case of nipa palm, it lacks an upright stem, with leaves and inflorescences arising from a branched rootstock [3]. The palm develops a globose infructescence, at a height of about $1 \mathrm{~m} \mathrm{[4],} \mathrm{which} \mathrm{makes} \mathrm{tapping} \mathrm{for} \mathrm{sap} \mathrm{relatively} \mathrm{easy.}$ Saps are generally collected from stalks bearing young or mature infructescence. The cut infructescence is generally consumed as local dessert. Therefore, tapping results in no biomass wastes and does not have any deleterious effect on the palm growth [5]. Hamilton and Murphy [6] emphasized the interest of nipa in terms of yield and management whereby tapping is easy, produces no waste and the environment protected, as it grows in brackish 
water environments where fresh and sea water mingle. Furthermore, Food and Agricultural Organization of the United Nations (FAO) [7] has declared the nipa palm as a nonthreatened and underutilized palm in South Asia. Therefore, abundant nipa palms are available for sap collection purposes in this region.

Currently, nipa palms are distributed all over Asia as natural and plantation-managed palms. The largest natural nipa stands of approximately 700000 ha are found in Indonesia, Papua New Guinea (500 000 ha), Philippines (8 000 ha) [8] and Malaysia (20 000 ha) [9]. The widespread occurrence of nipa palms made rural communities to grow these palms for limited use from sap to make toddy, vinegar or boiled down to sugar and the fruits used as local dessert. Even though, interests also emerged on the production of alcohol fuel from this resource but intensive research was never done or documented since Gibbs [3]. Consequently, the products from nipa saps remained in domestic use and its full potential is yet to be explored.

Therefore, the purpose of this study was to assess the sap production potential of nipa palms and further analyze the chemical and elemental properties of nipa saps. Additionally, fermentation studies were carried out to evaluate its fermentability and potential for ethanol production.

\section{Materials and methods}

\subsection{Sap collection site}

The nipa saps used in this study were collected from two habitation sites along Pak Phanang Basin, Nakhon Si Thammarat, Thailand. Pak Phanang Basin is located at $7^{\circ} 48^{\prime} \mathrm{N}$ to $8^{\circ} 31^{\prime} \mathrm{N}$ and $99^{\circ} 44^{\prime} \mathrm{E}$ to $100^{\circ} 2^{\prime} \mathrm{E}$ on the east coast of Southern Thailand. Topographically, the basin is a swampy area with sandy beach coast. Much of the lowland is used for rice farming and other uses such as shrimp farming. Four sites were chosen for this study which is located approximately $10 \mathrm{~km}$ from the sea and 5 to $10 \mathrm{~m}$ above sea level. 
Site I is a plantation managed over an abandoned shrimp pond, whereby it is under experimentation by our research group to restore these disused ponds. Site II, III and IV are plantations managed by local villagers on non-agricultural swampy lands. Site II and III are plantations located on low lands ( $5 \mathrm{~m}$ above sea level) with frequent flooding. Site III has a creek running through the site and is often flooded by brackish water. The moisture content in soils in Sites II and II are with 40 to $55 \%$, respectively. However, Site I and IV are on higher lands and have less than $30 \%$ moisture content in its soil. The soil electrical conductivity $(\mathrm{EC})$ was also done randomly throughout the sites. The EC values correspond to the amount of dissolved salts as electrolytes in soil and for Site I and IV, the values were in the range of 0.02 to $174 \mathrm{mS} \mathrm{m}^{-1}$. In Site II it was slightly higher from 20 to $320 \mathrm{mS} \mathrm{m}^{-1}$ and the highest in Site III from 18 to $1766 \mathrm{mS} \mathrm{m}^{-1}$.

Nipa palms at Site I are as young as 8 years old and palms at Site II are around $40 \mathrm{y}$ old. However, palms at Site III and IV are believed to be around 100 y old. Since nipa palm grows vigorously through its dichotomous root, we believe that the roots can be 100 y of age but palms which grow from them may be younger. The estimated areas of Site I, II, III and IV are $0.5,1.3,1.4$ and 0.8 ha, respectively.

\subsection{Sap tapping and collection}

The nipa palm density is 1000 ha $^{-1}$ with 140 to 200 palms tapped simultaneously per tapping season. In order to stimulate the flow, the stalk is manually beaten for $1-2$ weeks before tapping to soften the stalk tissues and thereafter, the infructescence is cut off and the stalk shaved once daily to have continuous flow of sap. The sap flow was measured everyday at $24 \mathrm{~h}$ intervals after tapping. The sap production potential in $\mathrm{L} \mathrm{d}^{-1}$ per palm for each site was measured based on the average daily saps collected from a single stalk of each palm. Local tapping practices were neither interfered nor altered during this study. 


\subsection{On-site analysis and pre-treatment}

Brix measurements (\%Brix) on collected nipa saps were done on-site using a portable digital refractometer HI 96801(Hanna Inst., USA) for its total sugar content determination. From our laboratory analysis, the actual total sugar content as analyzed by high performance liquid chromatography (HPLC) (LC-10A, Shimadzu, Japan) was 0.97 of the measured brix value. Therefore, our on-site data were adjusted accordingly from \%Brix to $\mathrm{g} \mathrm{kg}^{-1}$. Additionally, the collected saps were immediately subjected to heat treatment at $100{ }^{\circ} \mathrm{C}$ for 10 min to sterilize the saps and then kept in tightly stoppered bottle at room temperature. Detailed procedures and relevance of these techniques are described in Tamunaidu and Saka [10].

\section{$2.4 \quad$ Instrumentation and columns}

For individual sugars and ethanol determination in nipa saps, HPLC coupled with Shodex sugar KS-801 column (Showa Denko, Japan) was used with water as an eluent, running with a flow-rate of $1.0 \mathrm{~mL} \mathrm{~min}{ }^{-1}$ under column temperature of $80{ }^{\circ} \mathrm{C}$. Also for organic acids determination, HPLC coupled with Aminex fermentation monitoring column (Bio-rad, USA) was used with $1 \mathrm{mmol} \mathrm{L}^{-1}$ sulfuric acid as the eluent, running with a flow-rate of $0.8 \mathrm{~mL} \mathrm{~min}^{-1}$ under column temperature of $60^{\circ} \mathrm{C}$. All these elements were detected by a refractive index detector (RID-10A, Shimadzu, Japan). For elemental analyses, a small volume of the sap was incinerated at $600{ }^{\circ} \mathrm{C}$ for $2 \mathrm{~h}$ and analyzed by scanning electron microscope JSM-5800 (JEOL Ltd., Japan) coupled with energy dispersive X-ray instrument (Phoenix, USA), at an accelerating voltage of $20 \mathrm{kV}$. All these laboratory analyses for chemical and elemental compositions were done after $48 \mathrm{~h}$ of sampling. Samples were also analyzed before and after fermentation and quantification of inorganic elements were done using atomic absorption spectroscopy (AAS) (AA-6300, Shimadzu, Japan) with a highly sensitive graphite furnace atomizer and capillary electrophoresis system (CE) (G1600A, Agilent, Germany). Additionally, total nitrogen content was analyzed with element analyzer SUMIGRAPH NCH22F (Sumika Chemical Analysis Service, Ltd, Japan). 


\subsection{Batch Fermentation}

Yeast (Saccharomyces cerevisiae) (NBRC, Japan) was inoculated in Erlenmeyer flasks containing autoclaved medium (glucose $10 \mathrm{~g} \mathrm{~L}^{-1}$, peptone $5 \mathrm{~g} \mathrm{~L}^{-1}$, yeast extract $3 \mathrm{~g} \mathrm{~L}^{-1}$ and malt extract $3 \mathrm{~g} \mathrm{~L}^{-1}$ ), incubated in shaker at $2 \mathrm{~Hz}$ for $24 \mathrm{~h}$ at $28{ }^{\circ} \mathrm{C}$. Preliminary bioethanol fermentation was conducted by batch using $50 \mathrm{ml}$ fermentation flask sealed with rubber septum inserted with air filter through which $\mathrm{CO}_{2}$ was vented. Cultivated inoculum was added into sap sample and further diluted by the addition of nutrient (peptone $200 \mathrm{~g} \mathrm{~L}^{-1}$, yeast extract $120 \mathrm{~g} \mathrm{~L}^{-1}$ and malt extract $120 \mathrm{~g} \mathrm{~L}^{-1}$ ) or water as non-nutrient treatment. Fermentations were conducted on the same conditions among nipa saps, sugarcane sap and sucrose as a control with initial sugar content of $150 \mathrm{~g} \mathrm{~kg}^{-1}$. Fermentation was then done in duplicates in an incubator at $28{ }^{\circ} \mathrm{C}$ for a period of 0 to $48 \mathrm{~h}$. For comparison purposes, sugarcane sap was also studied and it was obtained from Miyakojima Island, Japan.

\section{Results and discussion}

\subsection{Sap production potential of nipa palms}

The yield of sap and its corresponding sugar content from tapped palms at each investigated site per tapping season is shown as Fig 1.

Site I, which is a plantation developed on an abandoned shrimp pond, produced nipa saps from 0.2 to $1.6 \mathrm{~L}$ for a maximum of 63 days with sugar contents from 159 to $188 \mathrm{~g} \mathrm{~kg}^{-1}$. The total sap collected per day in Site I was $144 \mathrm{~L}$ of sap from 140 palms, with an average of 1.0 L d $\mathrm{L}^{-1}$ per palm. Site II and III, however, comparatively had lower sap production, from 0.2 to $0.9 \mathrm{~L}$ for 47 days and 0.1 to $0.8 \mathrm{~L}$ of sap for 38 days, respectively. The average sap yields in Site II were of $0.6 \mathrm{~L} \mathrm{~d}^{-1}$ per palm from 200 palms tapped from this site. Site III averaged at $0.4 \mathrm{~L} \mathrm{~d}^{-1}$ per palm from 150 palms tapped simultaneously in one tapping season. Regardless, the sugar contents were high in both these sites in the range of 181 to $214 \mathrm{~g} \mathrm{~kg}^{-1}$ in Site II and 162 to $204 \mathrm{~g} \mathrm{~kg}^{-1}$ in Site III. Conversely, Site IV, with 100 year old palms, showed a high 
yield of sap production from 0.3 to $1.4 \mathrm{~L} \mathrm{~d}^{-1}$ for 42 days with an average of $0.8 \mathrm{~L} \mathrm{~d}^{-1}$ per palm. The corresponding sugar contents were in the range of 162 to $206 \mathrm{~g} \mathrm{~kg}^{-1}$.

However, taking into account sap yields, palm habitation, age and local tapping practices, the nipa sap production estimates varied within 0.4 to $1.0 \mathrm{~L} \mathrm{~d}^{-1}$ per palm with sugar contents from 159 to $214 \mathrm{~g} \mathrm{~kg}^{-1}$. Palms were tapped for 38 to 63 days per tapping season. It should be noted that in a year, tapping seasons vary within 2 to 3 cycles depending on the demand and use of nipa saps. Therefore, tapping days can be from 80 to 180 days per year. Similar studies by Päivöke [11] reported that nipa could be tapped for up to 100 days per year for a life span of more than 50 years, yielding a maximum of $1.3 \mathrm{~L} \mathrm{~d}^{-1}$ per palm of sugar sap. Studies in Philippines by Gibbs [3], reported an average yield of $0.6 \mathrm{~L}$ $\mathrm{d}^{-1}$ per palm of sugar sap based on tapping from 55 to 75 days.

An important observation was that, even palms of 100 years old in Site III and IV, could still produce competitive amounts of nipa saps with high sugar contents. The sap yields were comparatively lower in Site II and III but there were no distinctive differences between the palms raised in situ compared to Site I and IV, besides the high moisture content and salinity in the soil. The high frequency of flooding in Site II and III may have contributed to high salinity in the soil and consecutively low sap yields. Similar observations were also reported by Päivöke [11] from a study in Papua New Guinea. It was observed that high yielding palms did not normally grow by the river banks, but rather interior or on higher lands. High soil salinity and corresponding low sap yields were also discussed by Dennett [5]. However, the high salinity did not affect the sap quality in terms of sugar content as the sugar contents remained high as observed in both Site II and III.

However, some studies have shown that increased frequency of pre-treatment (beating) of stalks before tapping [3,12,13], longer length of stalks and younger palms [14] can contribute to higher sap yields. In Malaysia, the stalks are tapped twice daily instead of once and 2.5 to $3 \mathrm{~L}$ of sap can be collected based on our observation on a site visit there (unpublished data). Therefore, yields could differ from place to place depending on tapping practices, length of stalks, climate and also environment. This could be a challenge in 
obtaining nipa saps as tapping requires skillful pre-treatment and slicing of stalk, which can affect tapping duration of each stalk and corresponding yield of saps. However with skillful tapping, the lengthy duration and the long life span of nipa palm is favorable, as there is continuous production of rich sugar-sap with less cost and time spent on replanting.

\subsection{Chemical composition and inorganic elements in nipa saps}

One nipa sap sample is randomly chosen from each site to be further analyzed for its chemical composition. Table 1 shows the chemical composition of nipa saps collected from all the sites compared to sugarcane sap.

The nipa saps are mainly composed of sucrose, glucose and fructose, as observed in sugarcane sap, with small quantities of organic acids mainly lactic and acetic acid of 2 to 4 $\mathrm{g} \mathrm{kg}^{-1}$ and inorganics of $5 \mathrm{~g} \mathrm{~kg}^{-1}$. The total sugars in nipa saps were in the range of 174 to $186 \mathrm{~g} \mathrm{~kg}^{-1}$ and were comparable to sugarcane saps with $170 \mathrm{~g} \mathrm{~kg}^{-1}$. Furthermore, there were no significant differences in its chemical composition, confining to sugars, organic acids and inorganics. However, in the period of $48 \mathrm{~h}$ after sap collection, the total sugars became slightly lower in nipa sap compared to those detected on-site and simultaneously organic acids increased in saps. This could be due to autohydrolysis of sucrose to glucose and fructose and their further decomposition to organic acids.

Regardless, the sugar contents in nipa saps were found to be as competitive as other sugar-yielding palms such as sugar palm (Arenga pinnata) with 120 to $150 \mathrm{~g} \mathrm{~kg}^{-1}$ [15] and palmyra palm (Borassus flabellifer) from 180 to $220 \mathrm{~g} \mathrm{~kg}^{-1}$ [16]. However, sugar palm needs 10 to 12 years and palmyra palms from 20 to 30 years, respectively, before it could mature and be tapped for sap, compared to 5 years or less for nipa palm. Even though 5 years is rather long compared to sugarcane, nipa palm could produce saps continuously without cutting down the palm.

As mentioned previously, nipa palms grow in brackish water environments where fresh water and seawater mingle and elements like $\mathrm{Na}$ and $\mathrm{Cl}$ naturally exists. Fig. 2 shows 
the energy-dispersive X-ray (EDX) spectra of inorganic elements obtained as ash incinerated from nipa saps from all site in comparison to sugarcane sap.

The obtained spectra from nipa saps were similar to each other and consist of $\mathrm{Na}, \mathrm{Cl}$ and $\mathrm{K}$ as their major inorganic elements. Were different from one sap to the other, particularly nipa saps from Site II and III which had more intense $\mathrm{K}$ and $\mathrm{CI}$ peaks compared to sites I and IV. The intensity of the Na element, however, was almost similar in all saps. Additionally, low intensities of Mg, Si, P, S and Ca were also detected in all nipa saps.

Compared to nipa saps, the peaks for elements of $\mathrm{K}, \mathrm{Mg}, \mathrm{Ca}, \mathrm{S}$ and $\mathrm{P}$ were more intense in sugarcane sap. The high amounts of these elements in sugarcane sap directly corresponds to phosphate and potash fertilizers, calcinated lime, and gypsum used in sugarcane plantations. Elements of $\mathrm{Na}, \mathrm{Cl}$ and $\mathrm{Si}$ were also detected in sugarcane sap but in low intensities. Despite the intensities, both nipa and sugarcane sap consisted of the same elements with no heavy metals detected in both saps.

Since inorganic elements in saps appear to be affected by its habitation site, soil exhaustion of nutrients faced in sugarcane plantations is not applicable in terms of nipa plantation. The rich natural nutrients in sea water and its soil were sufficient for the palm growth, as observed in all our investigated sites. Furthermore, external addition of organic and inorganic fertilizers did not show any significant response in terms of nipa palm growth and sap yield as reported by our research members, Bamroongrugsa and Purintavarakul [17]. Therefore, management of nipa palm plantations over non-agricultural swampy lands and abandoned shrimp ponds are easy and sustainable for reestablishing a productive mangrove ecosystem as well as for economical purposes such as ethanol production.

\subsection{Fermentation of nipa saps with and without nutrient supplementation}

All nipa sap samples including sugarcane sap were subjected to batch ethanol fermentation. The initial sugar contents of all saps were adjusted to $150 \mathrm{~g} \mathrm{~kg}^{-1}$ before fermentation. The obtained ethanol yields of nipa saps with and without the supplementation of nutrients are 
shown as Fig 3. Sugarcane sap and pure sucrose fermentation was also done for comparison. The dotted line indicates the theoretical maximum amount of ethanol produced after total sugars are fully fermented is $0.51 \mathrm{~g} \mathrm{~g}^{-1}$ ethanol to sugar. This value is used as a basis for ethanol conversion rate from sugars, and the obtained results are summarized in Table 2. No corrections were made assuming that all sugars available will be converted to ethanol.

As observed in Fig. 3, the trends of ethanol yields were similar for all saps with or without nutrient supplementation. In nutrient-supplemented media, the fermentation of nipa saps were rapid in the first $12 \mathrm{~h}$ and were almost complete after $30 \mathrm{~h}$. In addition, its trend for fermentation and resulting ethanol yields were similar to sugarcane sap, in the range from 0.484 to $0.494 \mathrm{~g} \mathrm{~g} \mathrm{~g}^{-1}$ ethanol to sugar, with ethanol conversion from 94.1 to $96.9 \%$ within 30 to $32 \mathrm{~h}$. On the other hand, ethanol conversion from pure sucrose was slow, yet progressive even after $48 \mathrm{~h}$ in nutrient supplemented media.

Without nutrient-supplemented media, however, fermentation trends were similar to nutrient supplemented media but the fermentation was slower and highest ethanol yields of $0.487 \mathrm{~g} \mathrm{~g}^{-1}$ ethanol to sugar (95.5\% conversion) which were observed for sap from Site II. Overall, the ethanol conversions of all saps were over $70 \%$ without nutrient supplementation. Fermentation in sugarcane sap was also initially slower but started to increase after $28 \mathrm{~h}$ reaching $0.444 \mathrm{~g} \mathrm{~g}^{-1}$ ethanol to sugar in $48 \mathrm{~h}$. As for sucrose, it fermented well with nutrient supplementation, but without nutrients only $0.6 \%$ conversion was observed even after $48 \mathrm{~h}$ of fermentation.

Here, nutrient limitation could be a major factor responsible for the decline in fermentative activity during sucrose fermentation as also observed by Dombek and Ingram [18]. Nipa and sugarcane saps did not require external nutrients for fermentation and probably utilized naturally available nutrients in the form of nitrogen and inorganic elements. Therefore, nipa saps without nutrient supplementation were further analysed for total nitrogen and individual inorganic elements before and after fermentation. 
Changes in total nitrogen content before and after fermentation from nipa saps of all four sites is shown as Fig. 4. The highest nitrogen content in nipa sap before fermentation is $700 \mathrm{mg} \mathrm{kg}^{-1}$ as observed in Site I and the lowest in Site IV with only $400 \mathrm{mg} \mathrm{kg}^{-1}$. However, the change in total nitrogen content is only observed in Sites I, II and IV but no change at all in nipa sap from Site III. A total of 200 to $400 \mathrm{mg} \mathrm{kg}^{-1}$ of total nitrogen was consumed in Sites I, II and IV. Even though the amount is rather small, the nitrogen available could be consumed by microorganism for metabolism and growth in the fermentation media without nutrient supplementation.

Furthermore, some nutrients such as $\mathrm{Na}, \mathrm{K}, \mathrm{Mg}$ and $\mathrm{Ca}$ are required in small concentrations to satisfy cellular growth requirements to improve the ethanol fermentation and enhance ethanol productivity [19]. Several other researchers observed that ammonium [20], calcium and magnesium [21] have protective effects either on growth and fermentation or viability, which stimulate the fermentation rate and ethanol production. This resulted in the possibility to examine the role of natural inorganics in fermentation.

Therefore, nipa saps were further analyzed for the changes in inorganic constituents before and after fermentation. The total inorganic elements before and after fermentation for nipa saps is shown in Table 3.

As seen is Table 3, the total inorganic constituents consumed in nipa sap could be noticed with the reduction in its ash content from 4190 to $3384 \mathrm{mg} \mathrm{kg}^{-1}$ in sap from Site I, 4690 to $3904 \mathrm{mg} \mathrm{kg}^{-1}$ in Site II, 4832 to $4321 \mathrm{mg} \mathrm{kg}^{-1}$ in Site III and 4150 to $3160 \mathrm{mg} \mathrm{kg}^{-1}$ in Site IV. High amounts of $\mathrm{Na}, \mathrm{K}$ and $\mathrm{Cl}$ were present in the sap corresponding to the EDX spectra as shown earlier in Fig. 2. These elements were in a range between 935 and 1972 $\mathrm{mg} \mathrm{kg}{ }^{-1}$, slightly higher in sap from site III, due perhaps to high salinity. However, in the fermentation of these saps without nutrients, these elements remained even after $48 \mathrm{~h}$ of fermentation. Therefore, these elements could not be used efficiently for fermentation and probably added the stress factor for microorganisms to grow and produce ethanol under nutrient limitation. 
However, minor elements of $\mathrm{Mg}, \mathrm{Ca}, \mathrm{P}, \mathrm{S}$ and Si present in the saps were in the range between 4 and $255 \mathrm{mg} \mathrm{kg}^{-1}$, and these elements were found to be totally consumed or only found in a very small quantity in the sap after $48 \mathrm{~h}$ of fermentation. A total of 500 to 900 $\mathrm{mg} \mathrm{kg}^{-1}$ of these inorganic elements has been used in the fermentation process. From these lines of evidence, the presence of these elements in the sap may have supplemented for the growth and metabolism of the microorganism and further assisted in the alcoholic fermentation process.

The high fermentability of nipa saps to ethanol without nutrients is an additional advantage as nutrients are high cost, and therefore, economical to produce ethanol without them. These characteristics makes nipa sap an interesting feedstock to be exploited for sustainable ethanol production.

\subsection{Ethanol potential from nipa saps}

As a first step for the practical utilization, the potential of ethanol production from nipa sap was estimated. Based on the results obtained from sap collection, chemical characterization and fermentation, the total yield of ethanol in $\mathrm{L} \mathrm{ha}^{-1} \mathrm{y}^{-1}$ was estimated. The ethanol stoichiometric yield of $0.48 \mathrm{~g} \mathrm{~g}^{-1}$ was used as maximum yield achieved in conventional fermentation.

Consequently, the potential of ethanol production from nipa sap was estimated to $9100 \mathrm{~L} \mathrm{ha}^{-1} \mathrm{y}^{-1}$ of ethanol from the on-site and laboratory experimental data based on assumptions that 1000 palms ha-1 could be tapped for 100 days with a maximum sap yield of $1.0 \mathrm{~L} \mathrm{~d}^{-1}$ per palm containing a minimum sugar content of $150 \mathrm{~g} \mathrm{~kg}^{-1}$. However, the estimated potential of ethanol production could be almost half if only a minimum of $0.5 \mathrm{~L} \mathrm{~d}^{-1}$ per palm of sap could be obtained. Hence, the minimum potential could be $4550 \mathrm{~L} \mathrm{ha}^{-1} \mathrm{y}^{-1}$.

Nevertheless, the estimated annual ethanol yield from nipa sap of $4550-9100 \mathrm{~L} \mathrm{ha}^{-1}$ $\mathrm{y}^{-1}$ is as competitive as $5300-6500 \mathrm{~L} \mathrm{ha}^{-1} \mathrm{y}^{-1}$ estimated in sugarcane and $3100-3900 \mathrm{~L} \mathrm{ha}^{-1}$ $\mathrm{y}^{-1}$ for corn as reported by Marris [22]. Even though the range between minimum and 
maximum values is quite large, our estimated values are practical and can be used for development of future nipa palm ethanol industry, as important considerations such as palm habitation and sap yields, chemical compositions and sap fermentability have been covered in this study.

From the economic viewpoint, even though tapping of nipa saps could be laborintensive, it will create a considerable number of jobs and help generate sustainable livelihood for coastal communities. Furthermore, these palms could initiate coastal rehabilitation and restore degraded lands such as abandoned shrimp ponds as in Site I. Additionally, fossil energy inputs such as nitrogen, phosphate and potash fertilizers, herbicides and insecticides, machinery, irrigation, electricity, diesel fuel and gasoline used in sugarcane plantations has very limited use or not necessary in terms of nipa palm management.

\section{Concluding Remarks}

Nipa palms were found to produce high yields of sugar saps rich in sucrose, glucose and fructose similar to sugarcane. It was further found to be fermented to ethanol in high yields in both conditions with and without nutrient supplementation. Furthermore, the annual potential of ethanol yields from nipa sap was also as competitive as sugarcane and corn. Since nipa freely grows on swampy and sea adjacent land, deforestation caused by large clearing of forests as in sugarcane and corn is not foreseen. Therefore, ethanol produced from nipa saps may be more sustainable than conventional sugar and starch feedstocks that are currently available in the global market. 


\section{Acknowledgements}

The authors would like to thank $\mathrm{Dr}$ Hitoshi Miyasaka and Mr Keiyo Morimune from Environmental Research Center, The Kansai Electric Power Co. Inc, Kyoto, for their generous contribution to this research. We would also like to thank $\mathrm{Dr}$ Noparat Bamroongrugsa from Prince of Songkla University and the people of Pak Phanang Basin, Nakhon Si Thammarat, Thailand, for providing nipa sap samples for this research work. 


\section{References}

[1] Berg C. World fuel ethanol, analysis and outlook. Available at: http://www.meti.go.jp/report/downloadfiles/g30819b40j.pdf; 2004 [accessed 18.05.12].

[2] Dalibard C. Overall view on the tradition of tapping palm trees and prospects for animal production. Livestock Research for Rural Development. Available at: http://www.Irrd.org/Irrd11/1/dali111.htm; 1999 [accessed 18.05.12].

[3] Gibbs HD. The alcohol industry of the Philippine islands. Part I. A study of some palms of commercial importance with special reference to the saps and their uses. Philipp $\mathrm{J}$ Sci Sec A 1911;6:99-206.

[4] Uhl NW. Inflorescence and flower structure in Nypa Fruticans (Palmae). Am J Bot 1972;59(7):729-43.

[5] Dennett J. Final observations on the nipah palm as a source of alcohol. Malay Agric J $1927 ; 15(12): 420-32$

[6] Hamilton L, Murphy D. Use and management of nipa palm (Nypa fruticans, Arecaceae): A Review. Econ Bot 1988;42(2):206-13.

[7] Food and Agriculture Organization of the United Nations (FAO), Rome. Available at: http://www. fao.org/docrep/X0451E/ x0451e00.HTM; 1998 [accessed 15.01.10].

[8] World Agroforestry Centre, Kenya. Available at: http://www.worldagroforestrycentre.org/sea/Products/AFDbases/AF/asp/SpeciesInfo.a sp?SpID=18140; 2008 [accessed 21.06.11].

[9] Jabatan Pehutanan Semenanjung Malaysia, Malaysia. Prosiding seminar pengurusan dan pemuliharaan hutan nipah. Penang, Malaysia; February 25-26, 2009. 103pp. In Malay.

[10] Tamunaidu P, Saka, S. On-site sugar analysis and pre-treatment of nipa saps. In: Yao, T, editor. Zero-Carbon Energy Kyoto 2011. Special Edition of Jointed Symposium of Kyoto University Global COE "Energy Science in the Age of Global Warming" and Ajou University BK21, Japan: Springer; p. 121-26. 
[11] Päivöke AEA. Tapping practices and sap yields of the nipa palm (Nipa fruticans) in Papua New Guinea. Agric Ecosyst Environ 1985;13:59-72.

[12] Dennett J. A report on the nipah palm and the production of alcohol in British North Borneo. Malay Agric J 1925;13: 64-71.

[13] Bamroongrugsa N, Purintavarakul C, Kato S, Stargardt J. Production of sugar-beating sap from nipa palm in Pak Phanang Basin, Southern Thailand. Bull Soc Sea Water Sci Jpn 2004;58(3):304-12.

[14] Pratt DS, Thurlow LW, Williams RR, Gibbs HD. The nipa palm as a commercial source of sugar. Philipp J Sci Sec A 1913;8(6):377-98.

[15] Mogea J, Seibert B, Smits W. Multipurpose palms: the sugar palm (Arenga pinnata (Wurmb) Merr.). Agrofor Syst 1991;13(2):111-29.

[16] Morton JF. Notes on distribution, propagation, and product of Borassus palms (Arecaceae). Econ Bot 1988;42(3):420-41 .

[17] Bamroongrugsa N, Purintavarakul C. Growing nipa palm for restoration of abandoned shrimp ponds. Wetland Sci 2006;4(2):91-5.

[18] Dombek KM, Ingram LO. Nutrient limitation as a basis for the apparent toxicity of low levels of ethanol during fermentation. J Ind Microbiol 1986;1(4):219-25.

[19] Robin Robinett RS, George HA, Herber WK. Determination of inorganic cations in fermentation and cell culture media using cation-exchange liquid chromatography and conductivity detection. J Chromatogr A 1995;718(2):319-27.

[20] Jones AM, Thomas KC Ingledew WM. Ethanolic fermentation of blackstrap molasses and sugarcane juice using very high gravity technology. J Agric Food Chem $1994 ; 42(5): 1242-46$.

[21] Dombek KM, Ingram LO. Magnesium limitation and its role in apparent toxicity of ethanol during yeast fermentation. Appl Environ Microbiol 1986;52(5):975-81.

[22] Marris E. Drink the best and drive the rest. Natur 2006;444:670-72. 

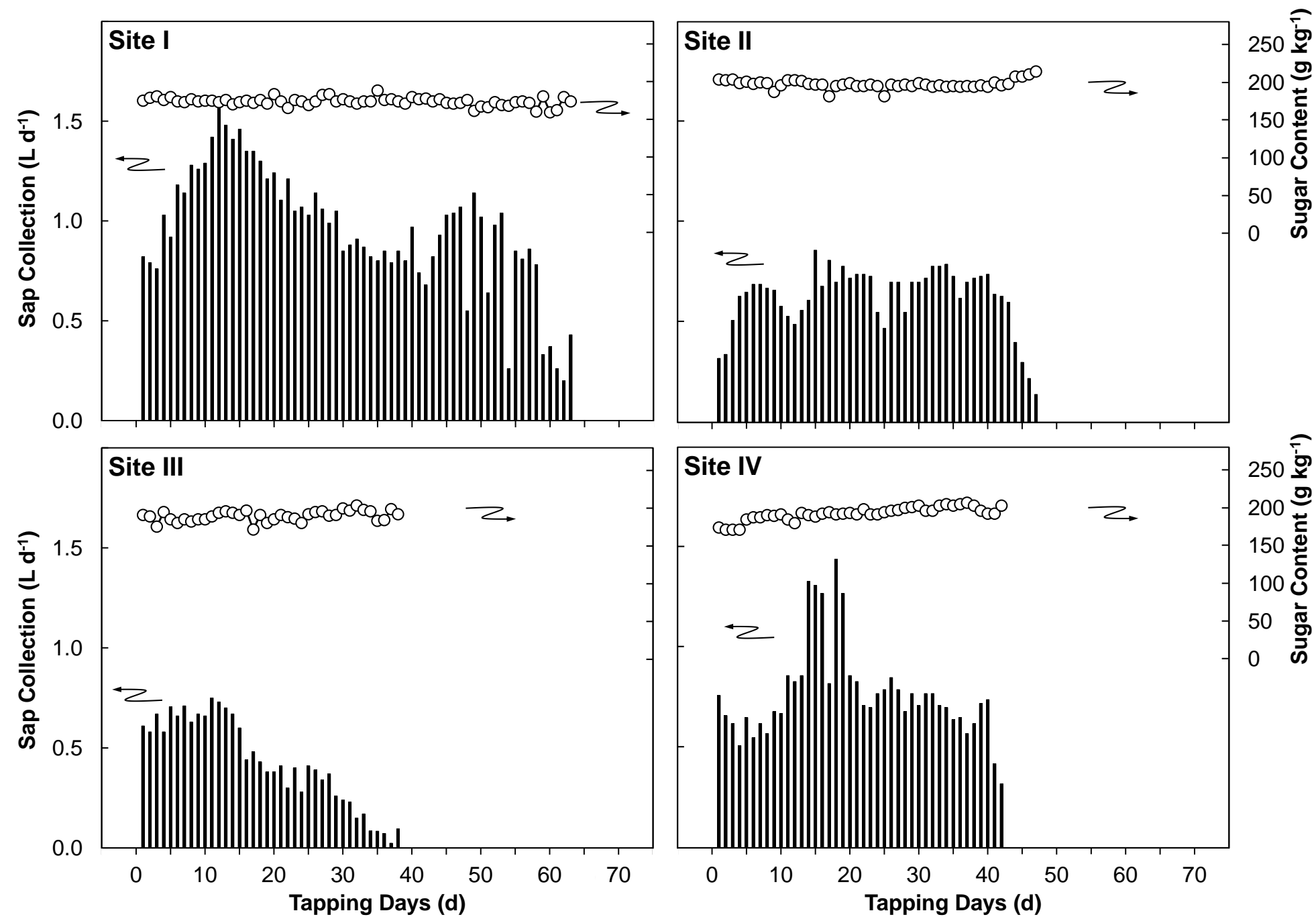

Fig 1 Sap yields, in $\mathrm{L} \mathrm{d}^{-1}$ and its corresponding sugar content, in $\mathrm{g} \mathrm{kg}^{-1}$, from palms investigated at all four sites during an entire tapping season. 
Table 1 Chemical composition of nipa saps from all four sites compared to sugarcane sap.

\begin{tabular}{|c|c|c|c|c|c|}
\hline \multirow{3}{*}{ Chemical composition } & \multicolumn{5}{|c|}{ Yield (wt\%) } \\
\hline & \multicolumn{4}{|c|}{ Nipa } & \multirow[t]{2}{*}{ Sugarcane } \\
\hline & Site I & Site II & Site III & Site IV & \\
\hline Total sugars on-site & 17.9 & 18.9 & 16.4 & 16.2 & - \\
\hline Total sugars & 17.4 & 18.6 & 16.0 & 15.9 & 17.0 \\
\hline Sucrose & 9.3 & 11.1 & 9.3 & 9.4 & 16.4 \\
\hline Glucose & 6.5 & 5.9 & 5.2 & 5.1 & 0.4 \\
\hline Fructose & 1.6 & 1.6 & 1.5 & 1.4 & 0.2 \\
\hline Organic acids & 0.2 & 0.4 & 0.4 & 0.3 & 0.0 \\
\hline Inorganics & 0.5 & 0.5 & 0.5 & 0.5 & 0.4 \\
\hline Total chemical composition & 18.1 & 19.5 & 16.9 & 16.7 & 17.4 \\
\hline
\end{tabular}




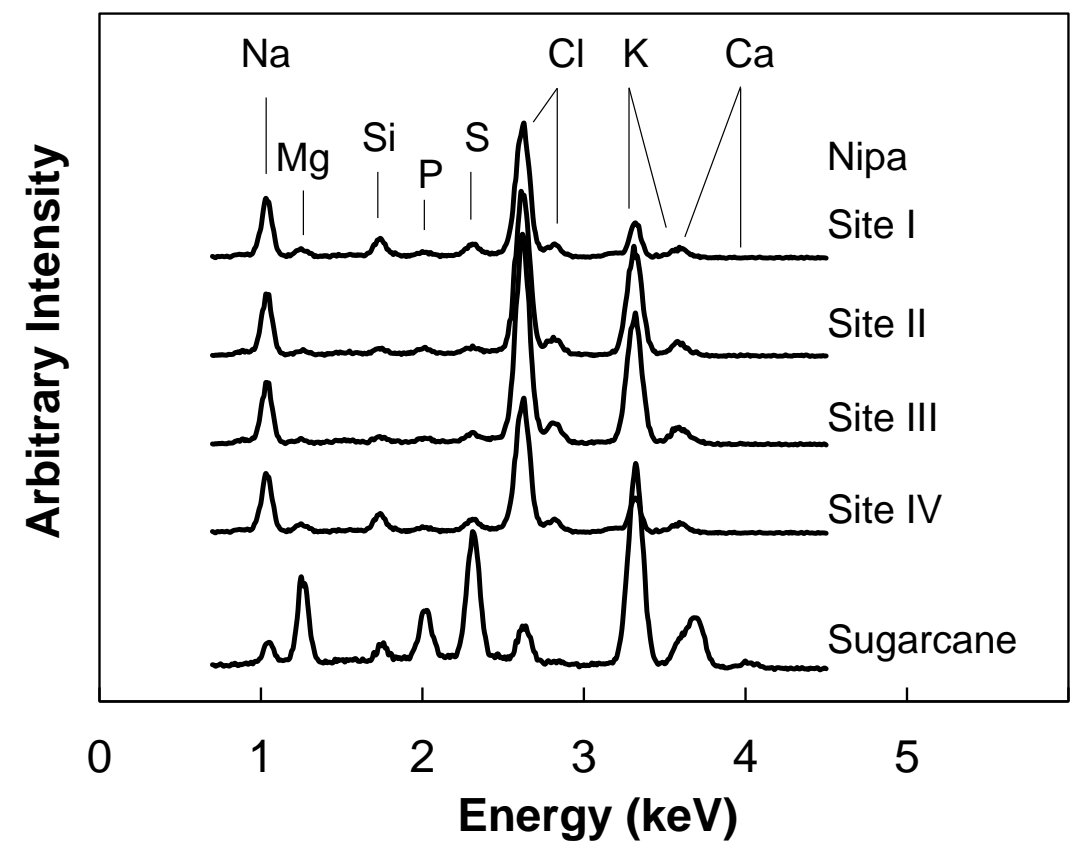

Fig 2 Energy dispersive X-ray (EDX) spectra of inorganic elements obtained as ash of nipa saps from all sites in comparison to sugarcane sap 

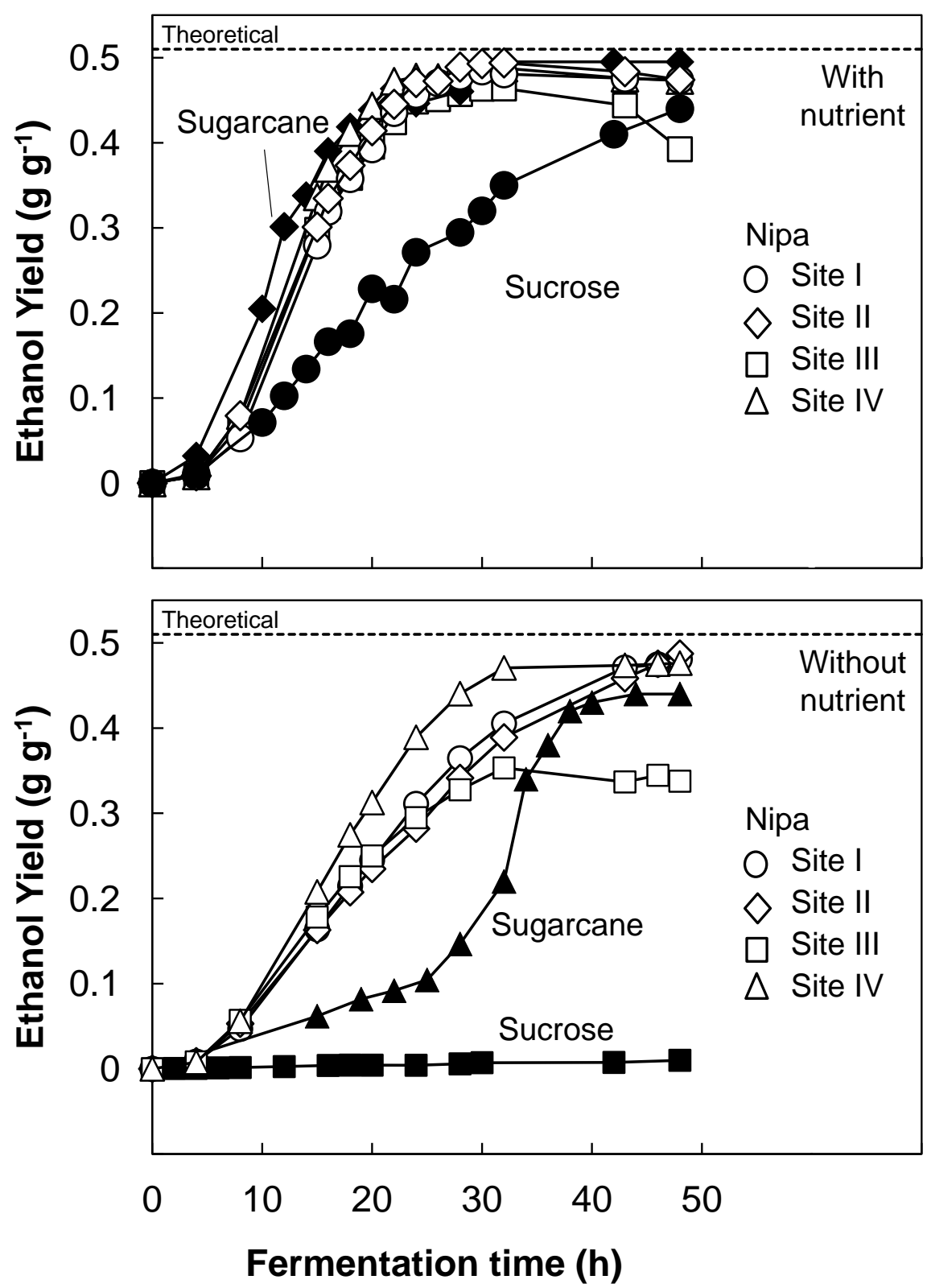

Fig 3 Ethanol yields for nipa saps with and without nutrient supplementation. Sugarcane sap and sucrose fermentation was done for comparison. 
Table 2 Fermentation summary of nipa saps with and without nutrient supplementation. Sugarcane sap and pure sucrose fermentation is done for comparison.

\begin{tabular}{|c|c|c|c|}
\hline & $\begin{array}{c}\text { Fermentation } \\
\text { completion time, } \mathrm{h}\end{array}$ & $\begin{array}{l}\text { Ethanol yield, } \\
\qquad \mathrm{g} \mathrm{g}^{-1}\end{array}$ & $\begin{array}{l}\text { Ethanol conversion } \\
\text { from sugar, } \%\end{array}$ \\
\hline \multicolumn{4}{|l|}{ With nutrients } \\
\hline \multicolumn{4}{|l|}{ Nipa } \\
\hline Site I & 30 & 0.484 & 94.9 \\
\hline Site II & 32 & 0.494 & 96.9 \\
\hline Site III & 32 & 0.464 & 91.0 \\
\hline Site IV & 30 & 0.489 & 95.9 \\
\hline Sugarcane & 32 & 0.495 & 97.1 \\
\hline Sucrose & 32 & 0.440 & 86.3 \\
\hline \multicolumn{4}{|c|}{ Without nutrients } \\
\hline \multicolumn{4}{|l|}{ Nipa } \\
\hline Site I & 48 & 0.480 & 94.1 \\
\hline Site II & 48 & 0.487 & 95.5 \\
\hline Site III & 48 & 0.361 & 70.8 \\
\hline Site IV & 48 & 0.476 & 93.3 \\
\hline Sugarcane & 48 & 0.444 & 87.1 \\
\hline Sucrose & 48 & 0.003 & 0.6 \\
\hline
\end{tabular}




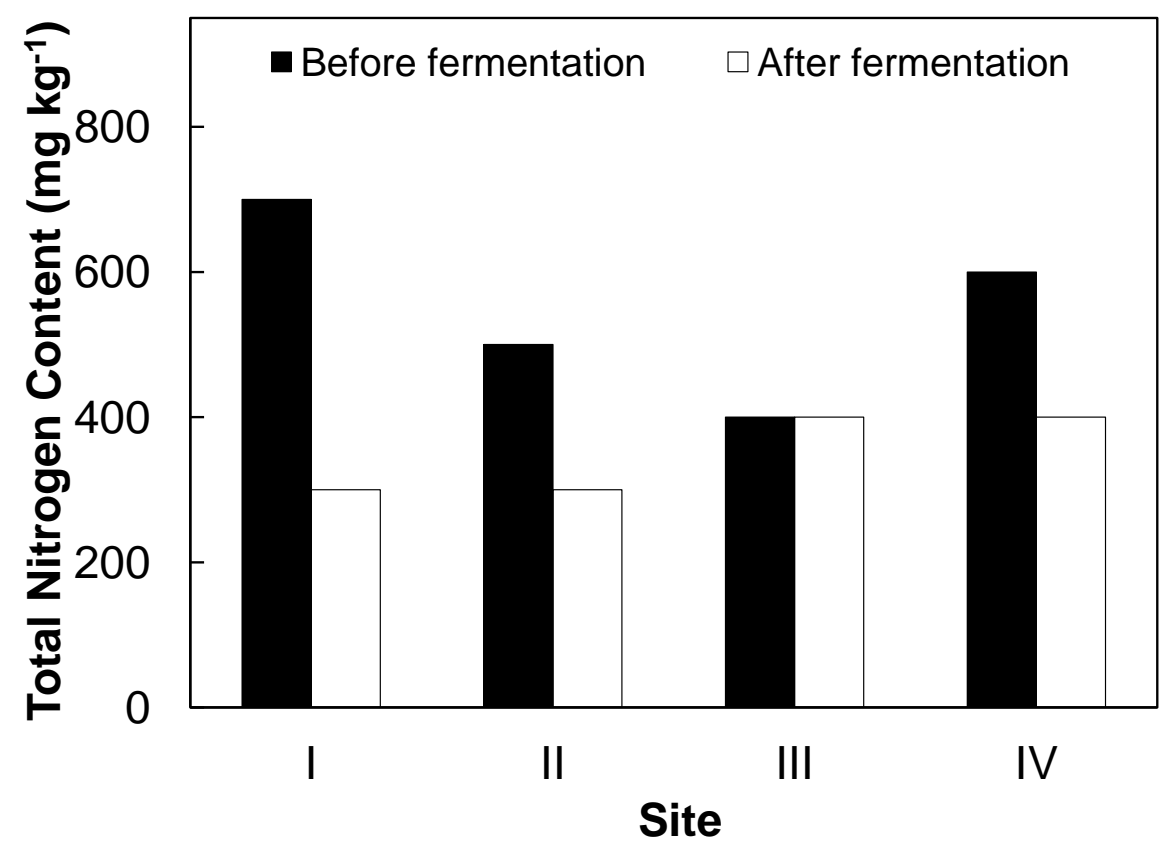

Fig 4 Changes in total nitrogen content before and after fermentation in nipa saps from various sites 
Table 3 Inorganic elements of nipa saps before and after fermentation without nutrient supplementation.

\begin{tabular}{|c|c|c|c|c|c|c|c|c|c|}
\hline & \multirow{2}{*}{$\begin{array}{c}\text { Ash } \\
\left(\mathrm{mg} \mathrm{kg}^{-1}\right)\end{array}$} & \multicolumn{8}{|c|}{ Inorganic constituents ( $\mathrm{mg} \mathrm{kg}^{-1}$ in sap) } \\
\hline & & $\mathrm{Na}$ & $\mathrm{K}$ & $\mathrm{Mg}$ & $\mathrm{Ca}$ & $\mathrm{P}$ & $S$ & $\mathrm{Si}$ & $\mathrm{Cl}$ \\
\hline \multicolumn{10}{|l|}{ Nipa } \\
\hline \multicolumn{10}{|l|}{ Site I } \\
\hline Before & 4290 & 1180 & 1700 & 30 & 25 & 255 & 90 & 75 & 935 \\
\hline After & 3484 & 1070 & 1604 & n.d. & n.d. & n.d. & n.d. & 10 & 800 \\
\hline \multicolumn{10}{|l|}{ Site II } \\
\hline Before & 4590 & 1212 & 1780 & 77 & 15 & 140 & 192 & 65 & 1109 \\
\hline After & 3804 & 1119 & 1699 & 7 & n.d. & n.d. & 5 & n.d. & 974 \\
\hline
\end{tabular}

Site III

$\begin{array}{lrrrrrrrrr}\text { Before } & 5032 & 1653 & 1872 & 73 & 4 & 70 & 55 & 96 & 1209 \\ \text { After } & 4597 & 1601 & 1829 & 10 & \text { n.d. } & \text { n.d. } & \text { n.d. } & 26 & 1131\end{array}$

Site IV

$\begin{array}{llllllllll}\text { Before } & 4350 & 1175 & 1760 & 45 & 10 & 205 & 110 & 65 & 980\end{array}$

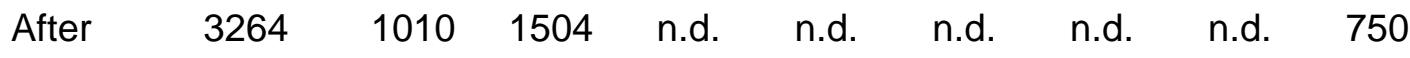

n.d.; not detected 